\title{
Geology versus myth: the Holocene evolution of the Sybaris Plain
}

\author{
Luigi Cucci \\ Istituto Nazionale di Geofisica e Vulcanologia, Roma, Italy
}

\begin{abstract}
Historical accounts handed down the legend of the ancient Sybaris, defeated and submerged by the Crotoniates who diverted the River Crati on the town. This paper deals with the reconstruction of the Holocene evolution of the Sybaris Plain, through a number of geological and geomorphological observations. In particular, I found i) $\sim 1 \mathrm{~m} / \mathrm{yr}$ horizontal coastal progradation rate since Greek times (2.4 kyr BP), possibly since Neolithic (7.0 kyr BP), mainly originated by active alluvial deposition and subordinately by regional uplift; ii) evidence of striking modifications in the surface hydrography of the plain during the last $2.5 \mathrm{kyr}$, with repeated fluvial captures of the Crati and Coscile rivers testified by ancient historians and geographers, recent maps and archeological accounts. In addition, datings and archeological information from 7 sites in the plain provided iii) $\sim 0.6 \mathrm{~mm} / \mathrm{yr}$ mean uplift rate during the past $11.2 \mathrm{kyr}$, that confirms the substantial continuity of this regional process with upper Pleistocene; iv) local, high value of subsidence $(0.5 \div 2.0 \mathrm{~mm} / \mathrm{yr})$ affecting the Sybaris main archeological area. Subsidence is not recorded before 4000 years BP and is caused by deposition of fine, highly compressible sediments at the transition between marine and continental environment; v) no evidence of a fault-induced contribution to the subsidence, whilst there is the grounded possibility that man-induced subsidence prevailed in the last century; vi) widespread active continental deposition in the area. Local rates of deposition are relatively lower $(1.5 \mathrm{~mm} / \mathrm{yr})$ at sites where subsidence is not observed, and range between $2.5 \mathrm{~mm} / \mathrm{yr}$ and $3.5 \mathrm{~mm} / \mathrm{yr}$ in the main archeological area. There is also evidence of a clear decrease of the sedimentation following the Mid-Holocene flex of the fast trend of sea level rise. These data suggest that the Holocene evolution of the Sybaris Plain is due to the progressive eastward migration of the land-sea boundary, probably active since the Mid-Holocene ( $\sim 7.0 \mathrm{ka})$. Repeated floodings, regional uplift and relative sea-level changes produced the eastward expansion of the plain, subsidence locally slowed it down. Therefore, geology first allowed the creation of Sybaris, then caused its destruction.
\end{abstract}

Key words Holocene - Sybaris - coastal progradation - uplift - subsidence

\section{Introduction}

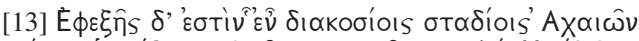

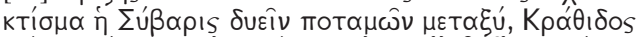

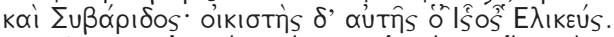

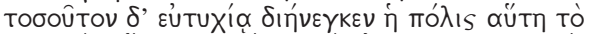

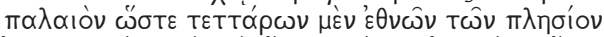

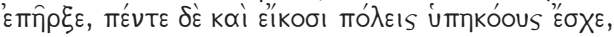

Mailing address: Dr. Luigi Cucci, Istituto Nazionale di Geofisica e Vulcanologia, Via di Vigna Murata 605, 00143 Roma, Italy; e-mail: cucci@ingv.it

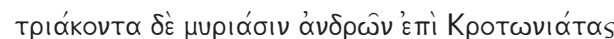

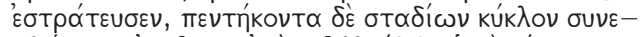

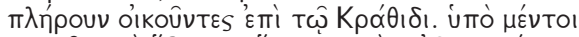

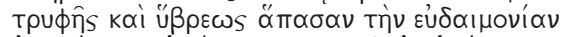

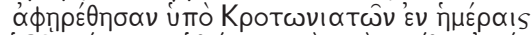

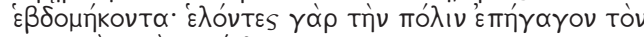

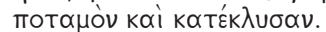

[13] Next in order, at a distance of two hundred stadia, comes Sybaris, founded by the Achæans; it is between two rivers, the Crathis and the Sybaris. Its founder was Is of Helice. In early times this city was so superior in its good fortune that it ruled over four tribes in the neighborhood, had twenty-five subject cities, made the campaign against the Crotoniates with three hundred thousand men, and its inhabitants on the Crathis alone completely filled up a circuit of fifty stadia. However, by reason of luxury and insolence they were deprived of all their felicity by the Crotoniates within seventy days; for on taking the city these conducted the river over it and submerged it.

(Strabo, Geography, VI, 1) 
Dramatic geological events often do help history to turn into legend. Catastrophic floods, megaearthquakes and great volcanic eruptions are the geological foundations that support mythological structures such as the Deluge and Atlantis. As from the tale of Strabo, one of the greatest geographers of antiquity, we learn the sudden and tragic fall of the flourishing Sybaris, destroyed and submerged by enemies coming from the rival town of Croton. The vanishing of the city and the long quest for its archeological ruins nourished an halo of mystery around Sybaris, and only in the late 60's was systematic search of the site rewarded. As we will see, the history of the ancient town is written in the sediments of the homonymous plain, and the most likely reason for its final disappearance comes from unfavourable geological processes. This paper presents a reconstruction of the Holocene evolution of the Sybaris Plain, a story of land uplift, sea-level changes, rivers' inundations, and local subsidence.

\section{Archeological settlements in the plain}

The most ancient traces of human colonization found in the region date back to the Neolithic (8000-4000 years BP) and to the Bronze Age (4000-3000 years BP) (Paladino and Troiano, 1989); remains of hamlets and necropoles during these periods were located along the belt of hills bordering the Plain, at some tens of meters elevation a.s.l. (fig. 1). These small villages increased and prospered also in the subsequent Iron Age (3000-2800 years BP). The Archaic Era marked the time when the broad and fertile plain became attractive for human settlement: in 720 B.C. Achæan people of Doric descent from the Peloponnese region found Sybaris right at the centre of the plain, close to the sea and between the Crathis and Sybaris rivers (currently Crati and Coscile rivers), which at the time had separate outfalls. The fast-growing town reached several hundred thousand inhabitants but in 510 B.C. it was completely destroyed following the war

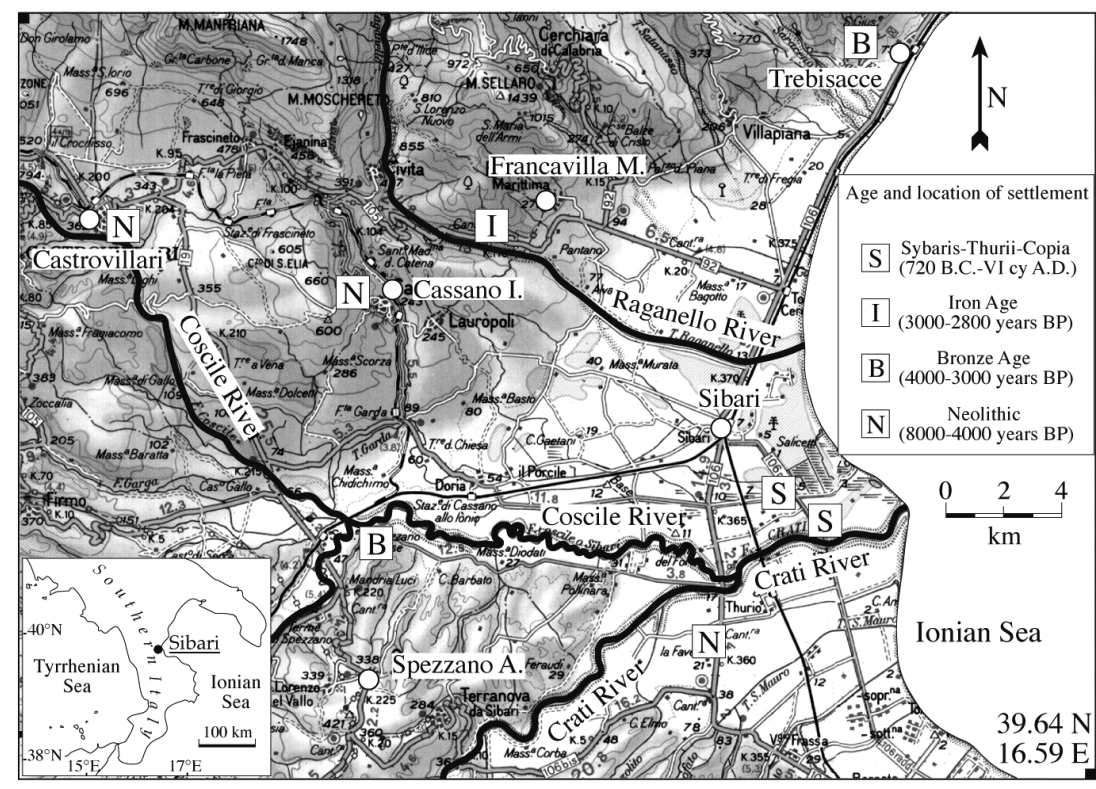

Fig. 1. Map of the study area: location of the Sybaris archeological site (founded in 720 B.C.) and of other archeological settlements between the Neolithic and the Iron Age (8000-2800 years BP) in and around the Sybaris Plain. Solid thick lines mark the three main rivers flowing in the Plain. The location of the modern Sibari and of the most important villages in the area is also shown. 


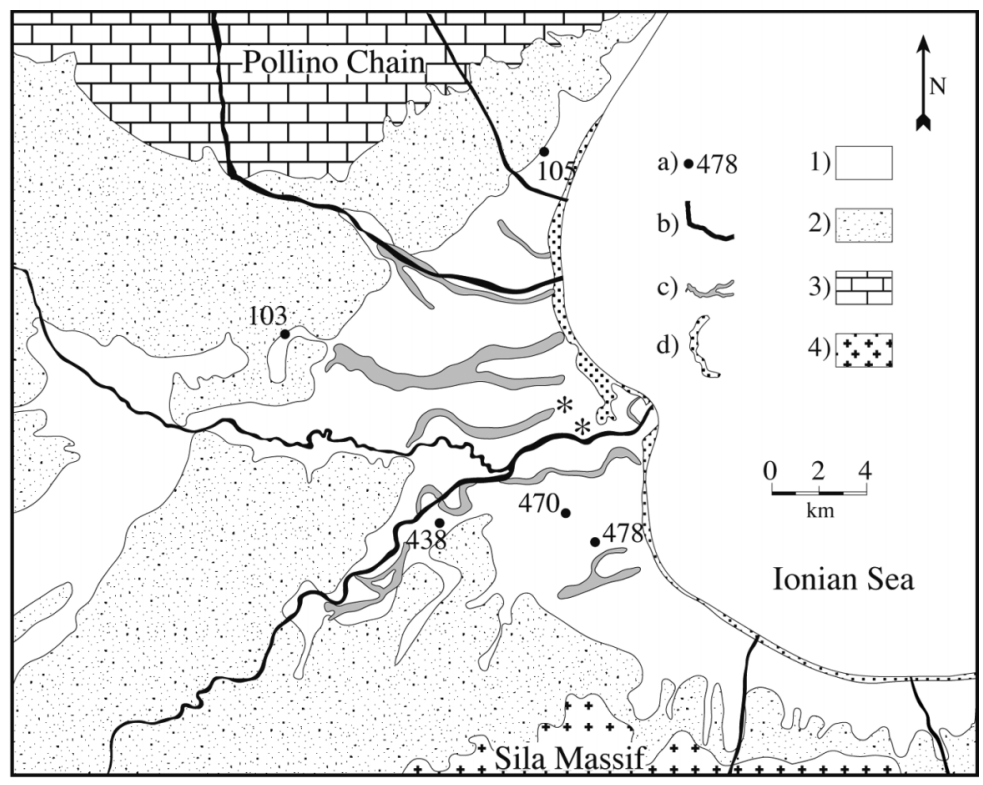

Fig. 2. Geological and geomorphological sketch of the study area (modified from Cotecchia, 1993). Geological legend: 1 - alluvial plain (Holocene-Upper Pleistocene); 2 - marine terrigenous and fan deltas deposits (middle Pleistocene-upper Pliocene); 3 - Campania-Lucania carbonate platform (Mesozoic); 4 - igneous and metamorphic rocks of the Calabride Complex (Paleozoic). Geomorphologic legend: a - Thickness (in meters) of the alluvial deposits; $\mathrm{b}$ - Modern riverbed; $\mathrm{c}$ - Paleo riverbed; $\mathrm{d}$ - Holocene dune. A star marks the location of the Sybaris archeological sites.

against the Crotoniates. The site was subsequently reoccupied in 444 B.C. with the foundation of the Hellenistic colony of Thurii which lasted until 203 B.C. Finally, in 194 B.C. the Roman colony of Copia was deduced on the same site of Thurii. Evidence of full activity of the city centre was still witnessed during the I century A.D.; subsequently, a slow decline initiated that lasted up to the V-VI century A.D., when the site was permanently abandoned (Paladino and Troiano, 1989).

\section{Geodynamic and geological outline}

Geological and geophysical evidence in the Central Meditarranean region (see, among others, Ogniben et al., 1975; Scandone, 1979; Malinverno and Ryan, 1986; Westaway, 1993; Gvirtzmann and Nur, 1999; Argnani, 2000; Jo- livet and Faccenna, 2000; Nicolich et al., 2000) supports a geodynamic model that assumes NNW-SSE slow convergence between Eurasia and Africa-Adria continental plates. Similarly, the tectonic evolution of the Calabrian Arc is commonly referred to such plates' convergence. The model also assumes southeastward rollback of the subducting slab located beneath the Southern Tyrrhenian Sea and well defined by seismicity distribution (Gasparini et al., 1982; Anderson and Jackson, 1987; Giardini and Velonà, 1991; Amato et al., 1993; Selvaggi and Chiarabba, 1995), tomographic images (Selvaggi and Chiarabba, 1995; Cimini, 1999; Lucente et al., 1999; Barberi et al., 2004), and Aeolian volcanism (Barberi et al., 1973). Complex dynamics associated with subduction and rollback produced throughout the Calabrian Arc back-arc extension, widespread uplift, and relative subsidence in the major tectonic basins where main- 
ly normal seismogenic faults accommodate internal deformation.

Located in the northeastern Calabrian Arc, the Sybaris Plain is one of the several alluvial plains that border the Italian Peninsula and the widest one in the Calabria Region (fig. 2). The plain is bounded on the landward side by the Pollino Chain to the north, and by the Sila Massif and the northern Crati Basin to the south and west. The Pollino Chain is mainly formed by Mesozoic limestones and dolomites of the Campania-Lucania carbonate platform, while igneous and metamorphic rocks of the Calabride Complex formation constitute the Sila Massif (Bigi et al., 1983; APAT, 2004). From a structural point of view the Plain is a graben originated during Pliocene-lower Pleistocene times (Ambrosetti et al., 1987); however, some evidence indicates that the fault systems bordering the graben are no longer active (Cucci, 2004), especially in the eastern half of the plain closer to the Ionian Sea.

During Upper Pliocene-Middle Pleistocene the former Sybaris Basin was progressively filled by fan deltas (Colella, 1988) and marine terrigenous sediments (fig. 2); these deposits are the terrains into which a well-developed suite of marine terraces is cut throughout the area, providing evidence for sustained uplift since upper Pleistocene times (Bordoni and Valensise, 1998; Cucci, 2004; Lambeck et al., 2004). An active submarine delta similar to the middle Pleistocene ones is presently developed at the mouth of the Crati River (Colella and Normark, 1984).

The upper part of the plain is filled by several hundred meter-thick Holocene alluvial gravels, sands and silts (fig. 2), mostly originated by the three main rivers Crati, Coscile and Raganello.

\section{Relative sea-level change in the Northern Calabrian Arc}

Relative sea-level change throughout the Calabrian Arc can be considered the combination of eustasy, isostasy and tectonics. Alternating glacial and interglacial periods result in eustatic fall and rise of global sea level; worldwide relative sea level curves (Lajoie et al., 1991; Bassinot et al., 1994; Waelbroeck et al., 2002; Siddal et al., 2003) indicate $\sim 120 \mathrm{~m}$ postglacial eustatic rise in global sea level due to Late Pleistocene-Holocene melting of former ice sheets. Following the Würm glaciation the most rapid $(\sim 10 \mathrm{~mm} / \mathrm{yr})$ eustatic rise occurred between 20 $18 \mathrm{ka}$ and 8-6 ka (Mid-Holocene), with continuing slower rise (1.5-2.0 mm/yr) thereafter (Lambeck et al., 2004).

Regional control on relative Holocene sea level is provided by glacio-hydro-isostatic movements due to the variable loading and unloading of ice and sea water masses on the crust during glacial cycles (Peltier and Andrews, 1976; Lambeck and Johnston, 1995). Estimates of the probable magnitude of isostatic effects in this sector of the Northern Calabrian Arc lie in the range of 1-2 $\mathrm{m}$ and of 4-7 $\mathrm{m}$ additional sea level rise since $2 \mathrm{ka}$ and $6 \mathrm{ka}$, respectively (Lambeck and Bard, 2000; Lambeck et al., 2002, 2004). Recently, Morhange et al. (2001) and Lambeck et al. (2004) published sea level curves that include both eustatic and glacio-hydro-isostatic contributions for the Central Mediterranean region.

Rapid uplift has been affecting the Calabrian Arc and the Sybaris region since late Pleistocene. Although a general consensus on the driving mechanism and on the time of onset of the uplift process is still lacking, a number of studies converge on assigning $\sim 1 \mathrm{~mm} / \mathrm{yr}$ as reference uplift rate in the Northern Calabrian Arc. In particular, Westaway (1993) suggested $\sim 1$ $\mathrm{mm} / \mathrm{yr}$ rate in the plain since $360 \mathrm{kyr}$ merely on the basis of geomorphological correlations with nearby regions, whilst Cucci and Cinti (1998) calculated an average rate of $0.67 \mathrm{~mm} / \mathrm{yr}$ during a maximum age interval of $\sim 0.6 \mathrm{Ma}$, and of $0.85 \mathrm{~mm} / \mathrm{yr}$ for the Holocene at the CalabriaLucania border ( $\sim 50 \mathrm{~km}$ north of the Plain). Recently, Cucci (2004) calculated a $0.98 \mathrm{~mm} / \mathrm{yr}$ rate over the last $124 \mathrm{kyr}$ in the northern part of the Plain and suggested a comparable trend of uplift for the Holocene. Moreover, analyzing datings from a core by Cherubini et al. (2000), Lambeck et al. (2004) find that the $0.87 \mathrm{~mm} / \mathrm{yr}$ tectonic rate estimated by Bordoni and Valensise (1998) on the basis of MIS 5.5 is likewise representative of the Holocene. South of the 
Sybaris Plain, the nearest estimates of uplift refer to the Crotone area $(\sim 100 \mathrm{~km}$ faraway) where Gliozzi (1988) found $0.83 \mathrm{~mm} / \mathrm{yr}$ of uplift rate since $123 \mathrm{ka}$, and Lambeck et al. (2004) calculated a rate of $\sim 1.15 \mathrm{~mm} / \mathrm{yr}$ on a raised Holocene paleoshoreline formerly observed by Pirazzoli et al. (1997).

\section{Novel geomorphological observations in the Sybaris Plain}

\subsection{Evidence of coastal progradation since Mid-Holocene}

Coastal progradation in the study area originated both by active deposition and by tectonic uplift. However, given the significant slope of the sea bottom $\left(2-3^{\circ}\right)$ and the relatively slow uplift rate $(\leq 1 \mathrm{~mm} / \mathrm{yr})$, the tectonic contribution to shoreline advancing is small $(\leq 0.05 \mathrm{~m} / \mathrm{yr})$.

On the contrary, coastal progradation originated by active alluvial deposition is witnessed throughout the region at least since 800 B.C. In South-Eastern Basilicata $(\sim 50 \mathrm{~km}$ north of Sybaris) the ancient Greeks who colonized the area also made accurate maps of the coastline (Adamesteano, 1974; Westaway, 1993). It emerges that the Holocene terrace in Basilicata is currently up to $2 \mathrm{~km}$ wider than in 800 B.C., with a consequent maximum rate of horizontal progradation of $\sim 0.7 \mathrm{~m} / \mathrm{yr}$. In the study area, the finding of a towpath at the Casa Bianca archeological site (fig. 3) suggests the presence during the Thurii period (2400 years BP) of a place for ship maintenance very close to the coeval coastline, 2.0 to $2.5 \mathrm{~km}$ inland from the modern sea: this provides a mean progradation rate of $\sim 0.9 \mathrm{~m} / \mathrm{yr}$. Further evidence of a general progradation of the coastline in the northern section of the plain is supported by the present position of the two medieval towers of observation set between the Crati River and the village of Trebisacce (fig. 3); these towers, built for warning and defence purposes next to the shoreline during the first half of the sixteenth century (Faglia, 1984), are now located $\sim 400 \mathrm{~m}$ away from the beach: this provides an approximate mean rate of horizontal progradation of $0.8-0.9 \mathrm{~m} / \mathrm{yr}$. More recent maps indicate that the delta of the Crati River has been prograding at a rate of $1.8 \mathrm{~m} / \mathrm{yr}$ since 1789 A.D. and 2.0 m/yr since 1935 A.D. (fig. 3).

Two more observations can be made regarding the period prior to the Archaic Era, both indicating former backward positions of the shoreline compared to the following ones. Firstly, the three archeological sites of Francavilla M., Spezzano Albanese and Trebisacce (fig. 1), that were permanently occupied between the Middle Bronze Age and the Early Iron Age (3600-2800 years BP), provide indirect evidence of a coast-

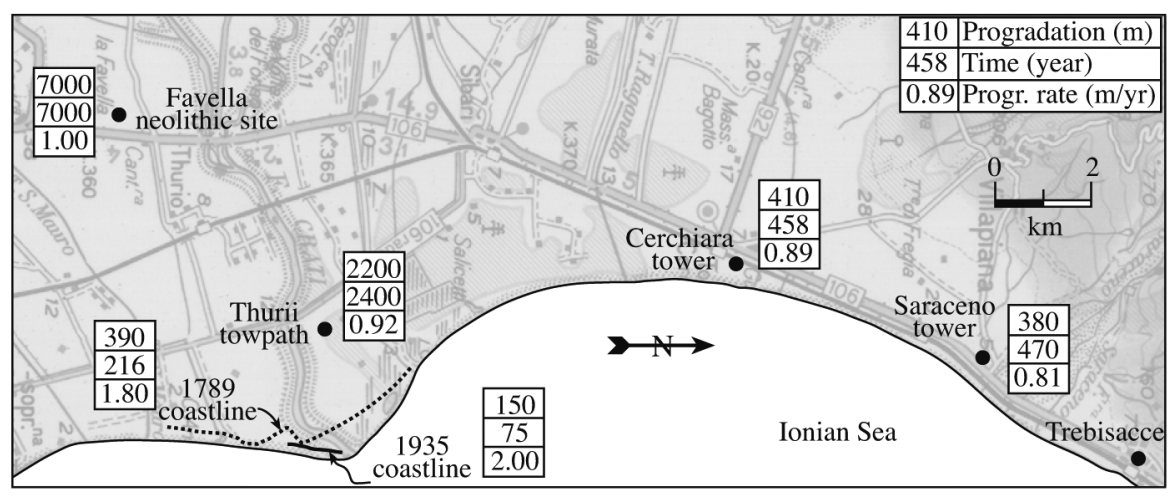

Fig. 3. Evidence of coastal progradation in the Sybaris area. A small table next to each site shows the estimated progradation and the time interval over which the corresponding progradation rate was calculated. 
line never behind those settlements during that period. The second observation comes from the Neolithic site of Favella della Corte, that dates back to $~ 7000$ years BP (Paladino and Troiano, 1989), and probably represents the first attempt of a permanent settlement within the Plain (figs. 1 and 3). Geoarcheological prospections and remote sensing analyses (Tiné and Traverso, 1993) revealed a paleoenvironment similar to a marshy wetland, with the neolithic hamlet located on a low fluvial terrace, surrounded by a Paleo Crati bed and not far from the sea. With the archeological site presently located $\sim 7 \mathrm{~km}$ from the modern sea it is possible to calculate an approximate maximum rate of progradation of $1.0 \mathrm{~m} / \mathrm{yr}$. It is interesting to note that the time of settlement of Favella della Corte roughly corresponds to the flex of the fast trend of sea level rise following the last glacial period (e.g., see the sea level curve of Lambeck et al., 2004 in fig. 8), thus indicating the earliest term when positive coastal progradation outpaced sea level changes and suggesting the farthest distance of marine ingression during Mid-Holocene.

\subsection{Modifications of the surface hydrography}

Most of the rivers in the Calabria Region are currently affected by highly variable seasonal regimes, exceptional solid load, and episodic dramatic floods. Not coincidentally then, the surface hydrography of the plain has been marked since historical times by striking changes. In the case of the Crati and Coscile rivers it has been possible to reenact the shifts of their outfalls assembling information from ancient historians and geographers and more recent maps and archeological accounts.

According to Herodotus, Strabo and Pliny the Elder the two rivers had distinct mouths until 510 B.C., whilst in the following century they were no longer separated (Thucydides, The Peloponnesian War, VII, 35, 1). No information was handed down for the next twenty centuries, during the long period of unhealthy environment and medieval economic decline. The first report following this period is the Tabula nova Italice by $\mathrm{M}$. Beneventanus, who mapped one single Crati-Coscile riverbed in 1508 A.D. (fig. 4a). Then, we find that Alberti in 1525 A.D. accurately describes two different riverbeds, but soon afterward the Crati and Coscile rivers are once again connected in Mercatore's (1554 A.D.) and Gastaldi's (1561 A.D.) maps. In the following two centuries two outlets are unanimously reported by many historical and geographical accounts: among these, the ones by Magini in 1608 AD (fig. 4b), by the Typographia Seminarii in 1699 A.D., and the map by Rizzi-Giannoni in 1771 A.D. which is the last of this series. Finally, the present pattern of the two rivers is first described in the Carta Generale del Regno di Napoli, Foglio 26, edited in 1789 A.D. (fig. 4c). From that time forth the Crati and Coscile rivers join $\sim 6 \mathrm{~km}$ from the Ionian Sea and show one single mouth.

Noticeably, the comparison between maps of different epochs provides evidence that the most striking surface modifications belong to the Crati River. The higher length of the latter, its extremely irregular regime and its higher slope especially $(2.7 \%$ against $1.9 \%$ over 10 $\mathrm{km}$ flow upstream of the confluence) are most likely reasons that concur to this process of cyclic fluvial capture toward the Coscile River. Further evidence supporting deep changes in the morphology of the Plain is testified by infrared aerial photo interpretation performed by Guerricchio and Melidoro (1975) who found significant traces of paleo riverbeds, fossil dunes and ancient marshy areas presently silted up.

\section{Below the ground at the Sybaris archeological site}

\subsection{Archeological excavations}

Archeological excavations off the left bank of the Crati River have led to the discovery of three superimposed levels of occupancy, that indicate continuous habitation between the 6th and the 1st centuries B.C.: the Archaic Sybaris, the Hellenistic Thurii and the Roman Copia (fig. 5). The remains are observed over a broad zone including the Parco del Cavallo and Casa Bianca areas closer to the river, and the Stombi area located $2 \mathrm{~km}$ northwest (fig. 6). These three sites display an unequal sequence of lev- 

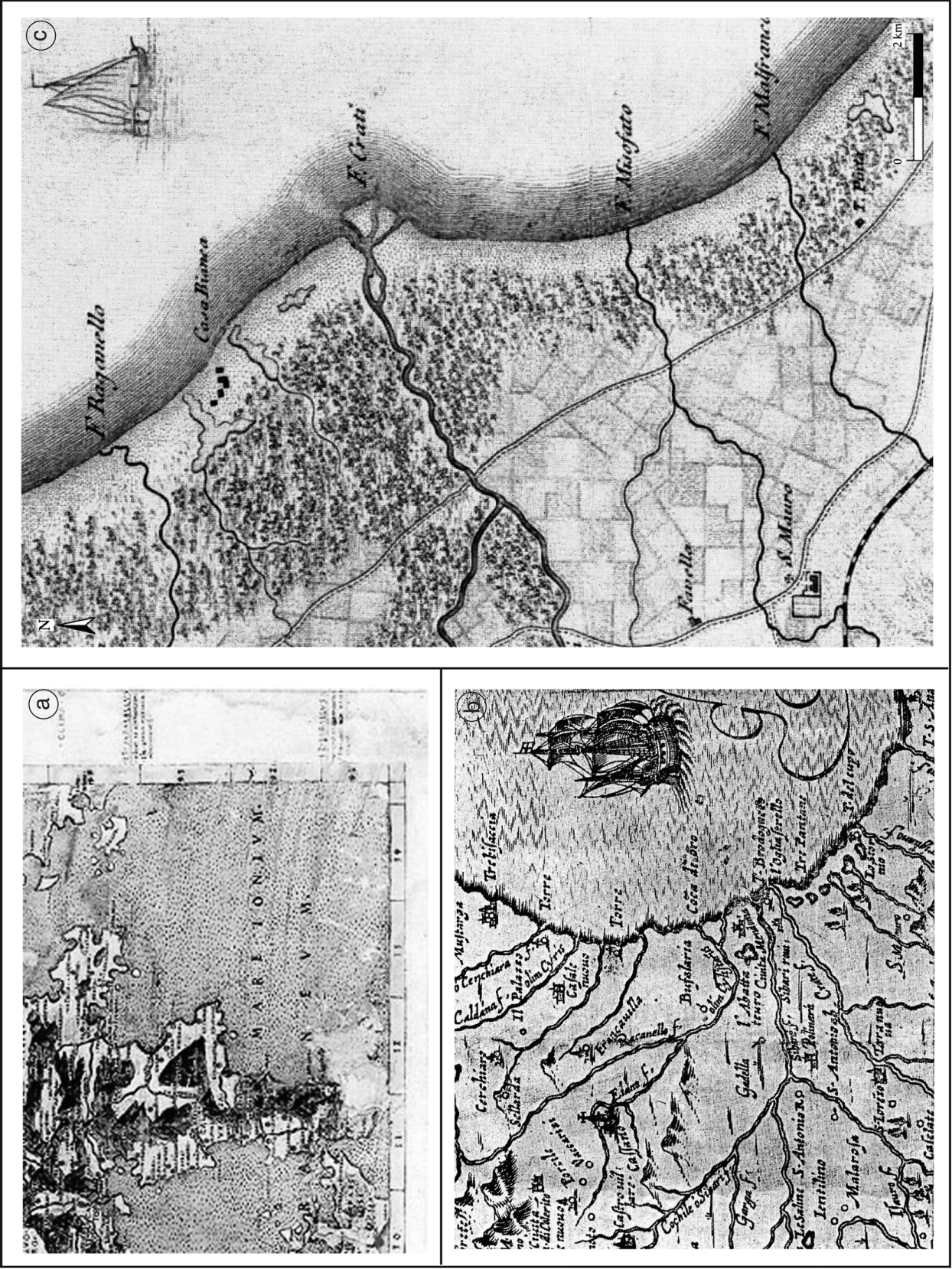

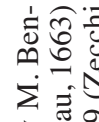

ลิษ

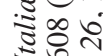

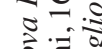

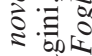

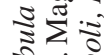

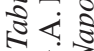

论

ह 0

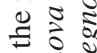

(ิ)

몽

는

을

ำ

สㅇํㄴ

워

$\Xi$ 年

츨클

츤음

인?

고으믈

인

冚

क $\frac{0}{00}$

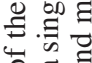

.

चू

: ?

웡 잉

.0

ব웛

on $\Xi$ ?

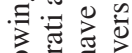

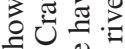

क $\frac{0}{5}$

है

运的気交

웅 : 옹

约豞

ن⿺辶⿻

茟

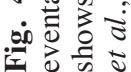




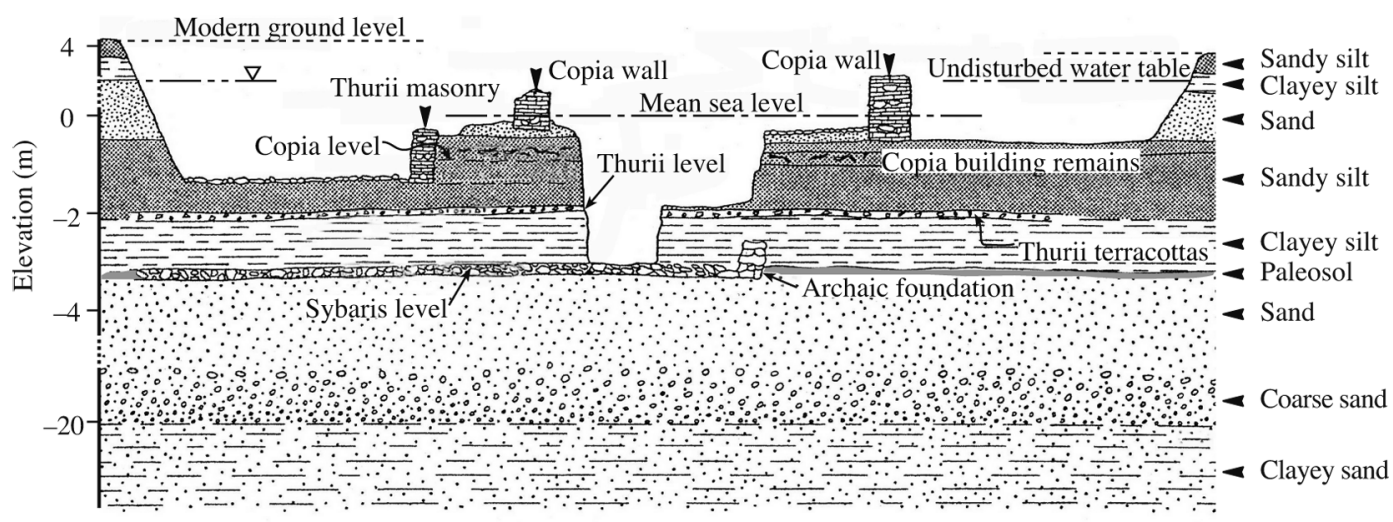

Fig. 5. Ideal section at the Parco del Cavallo archeological site (modified from Cotecchia, 1993); the section is representative of the ground beneath the surface. The draft is not in scale.

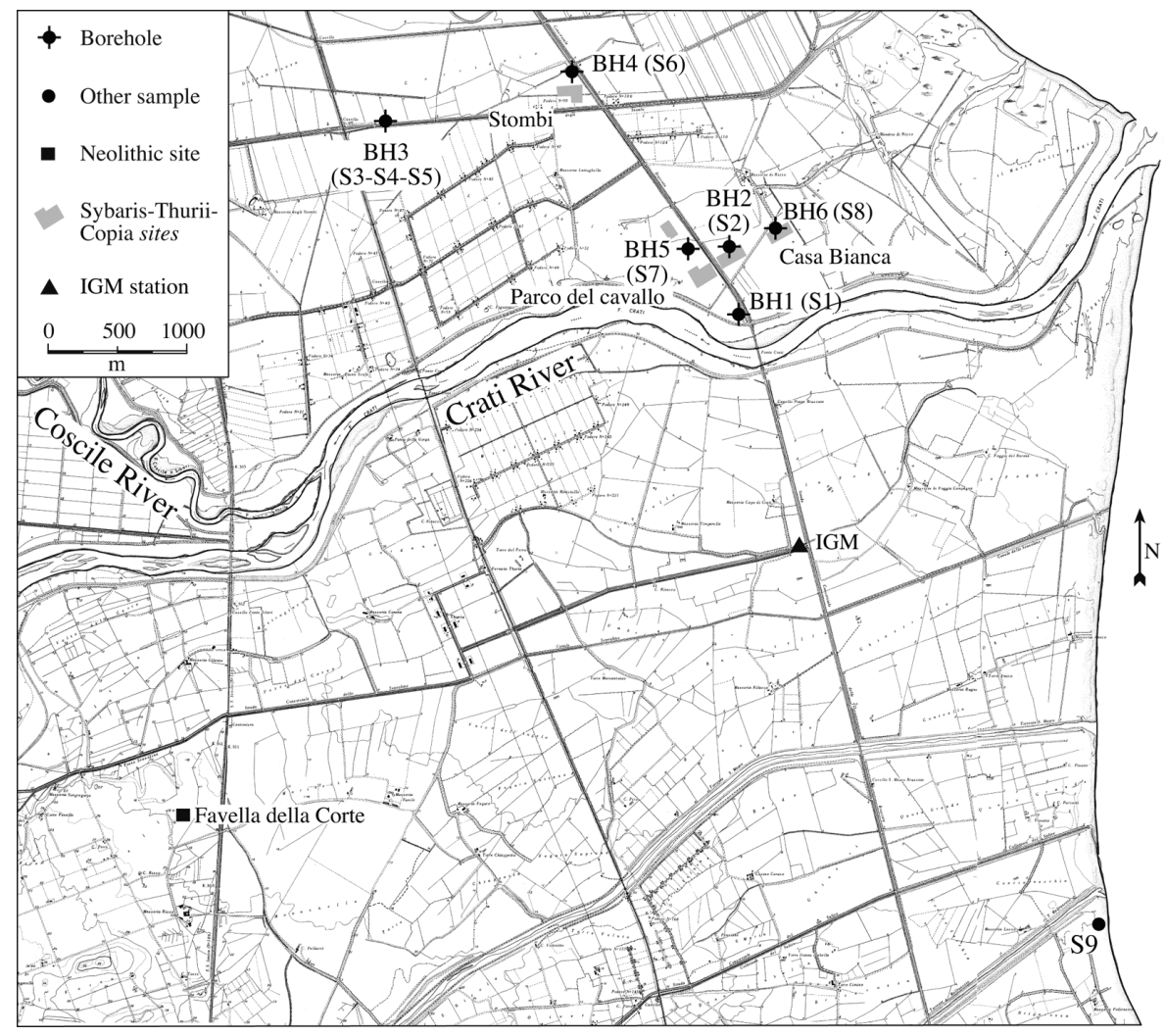

Fig. 6. Topographic map of the Sybaris archeological sites and adjacent areas, with the location of the boreholes and of the samples described in the main text. The map also reports the location of the IGM geodetic benchmark. 


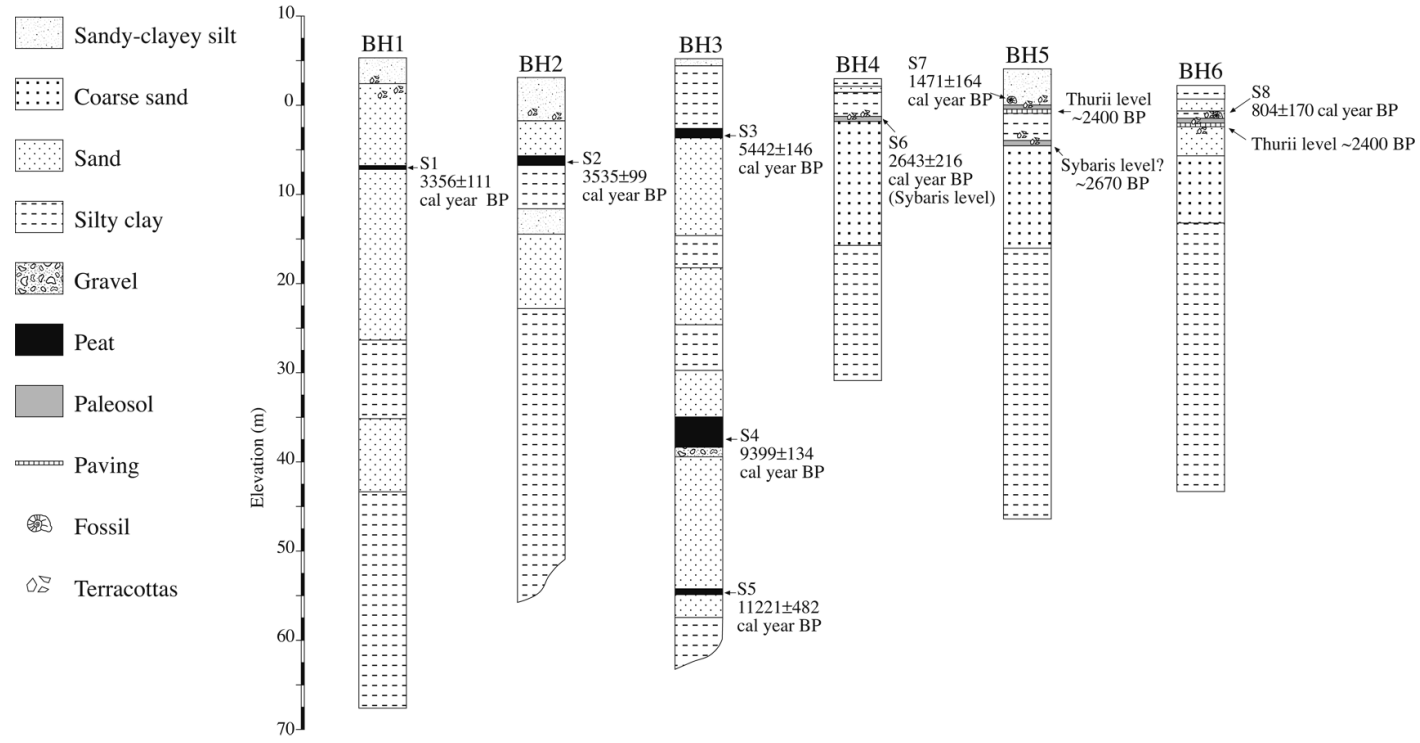

Fig. 7. Stratigraphies of the six boreholes in the archeological area, with the location of the dated samples and their calibrated radiocarbon ages (in years BP). The position of the Sybaris and Thurii-Copia levels is also indicated.

els that are possibly related to different geomorphological conditions. Excavations have found all three historical levels only at Parco del Cavallo; at Casa Bianca there are no remains of the Archaic Sybaris, which instead is the only settlement at Stombi.

The archeological site is located at the centre of the Plain (figs. 1 and 6), where the alluvial deposits that fill the upper part of this depression reach the maximum thickness of $\sim 400 \mathrm{~m}$ (Cotecchia, 1993) (fig. 2). Holocene barren deposits normally consist of sands and coarse sands, although locally in the upper part of the sequence lenses of finer clays and coarser gravels can be observed. Some rare levels with peats are found at various depth. Lithologies and grain size indicate environments of deposition passing from the littoral through the intertidal to the fluviodeltaic zone, with episodic marshy areas.

A clear surface of discontinuity on top of the sands marks the separation with a blackish paleosol above (figs. 5 and 7); this probable erosional surface represents the oldest level of occupan$\mathrm{cy}$, as the paleosol contains organic remains, fragments of terracotta and paving. This level is covered by silty deposits with peat levels typical of a lagoon environment and by sandy and clayey silts originated by fluvial inundations.

At present, the ground level throughout the area lies at an elevation of 3-5 $\mathrm{m}$ a.s.l. (fig. 5); the oldest archeological level, corresponding to the Archaic Sybaris, is found up to $3.5 \mathrm{~m}$ b.s.l., whilst the Roman Copia level is at $-0.5 \mathrm{~m}$ altitude (fig. 5). Before the excavations all the archeological remains lay below the water table, about $0.8-1.5 \mathrm{~m}$ below the surface; after the diggings a well-point system has been depressing the ground water level at the archeological site just below mean sea level.

\subsection{Datings from cores at the archeological site}

Late Pleistocene regional uplift rates and clear evidence of modern active coastal progradation and dramatic changes in the surface hydrography in the plain are a first contribution to reconstruct the Holocene history of the site and 
Table I. Summary of the data related to the samples in the Sybaris archeological area. The observed elevation is expressed in meters above or below mean sea level. The corrected elevation of S7 is shown in italics (see also the main text and fig. 8). All radio carbon dates were calibrated using the Stuiver et al. (1998) calibrations. The net uplift or subsidence is calculated as the difference of the elevations between the dated sample and the corresponding point on the paleo sea-level curve in fig. 8.

\begin{tabular}{lcccccc}
\hline \hline Sample & Altitude $(\mathrm{m})$ & $\begin{array}{c}\text { Altitude } \\
\text { error }( \pm \mathrm{m})\end{array}$ & $\begin{array}{c}\text { Age } \\
(\text { cal years BP) }\end{array}$ & Marker & $\begin{array}{c}\text { Net uplift/ } \\
\text { subsidence }(\mathrm{m})\end{array}$ & $\begin{array}{c}\text { Rate of uplift/ } \\
\text { subsidence }(\mathrm{mm} / \mathrm{yr})\end{array}$ \\
\hline S1 & -7.00 & \pm 3 & $3356 \pm 111$ & Peat & -3.79 & -1.13 \\
S2 & -6.30 & \pm 3 & $3535 \pm 99$ & Peat & -2.58 & -0.73 \\
S3 & -2.75 & \pm 3 & $5442 \pm 146$ & Peat & 4.14 & 0.76 \\
S4 & -37.50 & \pm 3 & $9399 \pm 134$ & Peat & 0.47 & 0.05 \\
S5 & -54.90 & \pm 3 & $11221 \pm 482$ & Peat & 10.66 & 0.95 \\
S6 & -1.35 & \pm 3 & $2643 \pm 216$ & Charcoal & 0.87 & 0.33 \\
S7 & $0.20(-1.80)$ & 0 & $1471 \pm 164$ & Helix & $\leq-0.72$ & -0.49 \\
S8 & -2.15 & $+0 /-2$ & $804 \pm 170$ & Cerastoderma & -1.58 & -1.97 \\
S9 & 2.60 & \pm 3 & $620 \pm 118$ & Wood & 2.89 & 4.67 \\
\hline
\end{tabular}

to evaluate how uplift, subsidence and overflooding affected this area. To collect informations concerning the period between the MidHolocene and historical times, six boreholes were chosen among those drilled in the last decades in and around the Sybaris area for archeological and geological investigations. These boreholes (hereinafter $\mathrm{BH}$ ) report ${ }^{14} \mathrm{C}$ datings of peat levels, carbon frustules and fossils that were found between $+0.20 \mathrm{~m}$ and $-54.90 \mathrm{~m}$ altitude (see table I that summarizes the ${ }^{14} \mathrm{C}$ datings). Figure 6 illustrates the locations of the cores, of the archeological areas and of the neolithic site of Favella della Corte. Figure 7 shows the logs of the $\mathrm{BH}$ along with the calibrated radiocarbon ages of the samples collected (all the datings were originally not calibrated ${ }^{14} \mathrm{C}$ ages) and the age of the archeological levels.

BH 1-2-3 (fig. 7) were firstly presented by Cherubini et al. (2000); two of them are located within the main archeological area, the third one was drilled $\sim 2.5 \mathrm{~km}$ WNW from it, in the western part of the Stombi site (fig. 6). Five samples (numbered $\mathrm{S} 1$ to $\mathrm{S} 5$ ) from peat and marsh deposits in the depth range $-2.75 \div$ $\div-54.90$ m below present sea level yielded ${ }^{14} \mathrm{C}$ calibrated ages in the interval $3.4 \div 11.2 \mathrm{kyr} \mathrm{BP}$ (table I).
BH 4-5-6, carried out by Guerricchio and Melidoro (1975) as support to the archeological excavations, are located in the Stombi, Parco del Cavallo and Casa Bianca areas (fig. 6). A charcoal sample (S6) found at $-1.35 \mathrm{~m}$ depth b.s.l. in $\mathrm{BH} 4$ at the base of the paleosol corresponding to the Archaic Sybaris (fig. 7) was radio carbon dated at $2.6 \mathrm{ka}$ (table I), comparable to the age of the archeological level. The Helix sample S7 in BH5 (fig. 6) provided a ${ }^{14} \mathrm{C}$ calibrated age of $1.5 \mathrm{kyr} \mathrm{BP}$ (table I); this shell was found at +0.20 altitude in a level immediately above the Thurii-Copia remains (fig. 7), so that it postdates the human ancient frequentation and indicates the period of permanent abandon. BH6 provided Cerastoderma lamarcki shells that were radio carbon dated at $0.8 \mathrm{ka}$ (fig. 6 and table I); also this sample (S8) was found (at -2.15 b.s.1.) in the upper part of a paleosol that covers the Thurii-Copia pavement (fig. 7). Similarly to the Helix sample from BH5, the Cerastoderma shells indicate a change in the environment which turned into marshy or lagoonal conditions after the site was abandoned (archeologically set during the V century A.D. by Paladino and Troiano, 1989).

In the area one more available dating is from a wooden sample (named S9) observed by Cotecchia et al. (1969) at $+2.60 \mathrm{~m}$ in a peaty 
level resting on sand deposits along the coastline, $6 \mathrm{~km}$ SE of the main archeological area (fig. 6). This sample gave a calibrated radio carbon age of $0.6 \mathrm{ka}$ (table I), although the authors state uncertainties on the origin of the peaty level, whether it was a paleosol or a plant accumulation driven by surficial waters.

\section{Uplift, subsidence and overflooding in the plain}

\subsection{Uplift}

It is now possible to reconstruct the Holocene morphological evolution of the plain on the basis of the ${ }^{14} \mathrm{C}$ datings and the geomorphological data already described. The first step is to determine if the coastal area was affected during this period by vertical tectonic motions such as regional uplift and/or local subsidence. Such tectonic contribution is evaluated as the difference between observed local sea level positions and predicted Holocene sea level curve for the same site; in this case, we adopted the curve by Lambeck et al. (2004) shown in fig. 8 as i) it accounts for eustatic and glacio-hydro-isostatic effects and ii) it is specific for Southern Italy. The local sea level positions are provided by the dated samples; therefore, the amount of effective tectonic displacement is simply given by the graphical distance between the data points and the predicted sea level curve in fig. 8 .

Uncertainties associated with the dated samples as paleo sea level indicators are generally limited (table I). Peat and charcoal samples of marshy environment (samples S1 to S6 and S9), usually representing upper limits to sea level, were collected near the lower part of the deposits (Cotecchia et al., 1969; Cherubini et al., 2000) where the effects of compaction are negligible; therefore, the error bars adopted in this case are between +3 and $-3 \mathrm{~m}$. Although the pulmonate gastropod Helix can be observed over a very wide range of altitudes, in the case of sample S7 we can infer a minimum altitude of $2 \mathrm{~m}$ above the ancient sea level, i.e. the minimum height of survival of this mollusk in an environment adjacent to the coastline; this value will provide a maximum tectonic uplift rate

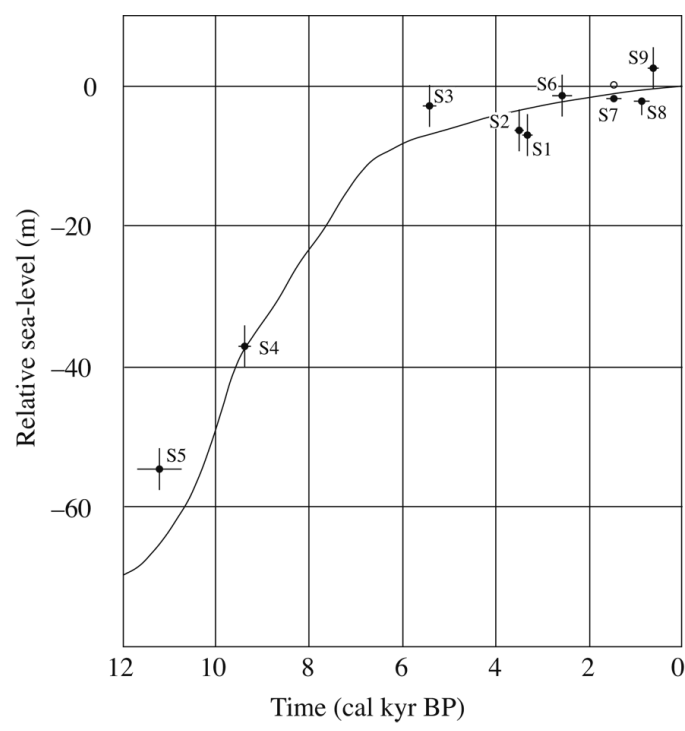

Fig. 8. Comparison of Holocene predicted sea-level curve for Calabria and observed data (solid circles with error bars). The empty circle is the uncorrected observed value for $\mathrm{S} 7$, i.e. the only sample that is not directly referred to an ancient sea level. For samples data see table I (sea-level curve from Lambeck et al., 2004).

for this sample. Finally, mollusks Cerastoderma lamarcki define a typical lagoonal environment bottom, and the error associated with the paleo depth of sample S8 is estimated between 0 and $-2 \mathrm{~m}$.

Figure 8 shows the comparison between predicted sea level curve by Lambeck et al. (2004) and elevation of the 9 aged samples from the Sybaris area. The observed data points show contrasting signals that reflect non uniform response to local and regional processes. The first observation is that S3-S4-S5 older samples concordantly indicate uplift; these samples come from the same borehole and provide a mean uplift rate of $0.59 \mathrm{~mm} / \mathrm{yr}$. A further consideration concerns $\mathrm{S} 4$ and its relatively low uplift rate $(0.05 \mathrm{~mm} / \mathrm{yr}$, table I) when compared to the other samples from the Stombi site; a possible explanation of this value is that $\mathrm{S} 4$ is the only sample coming from a thick level of peat deposit, that might have undergone pri- 
mary compaction after deposition, with a consequent decrease of the total uplift of the dated level. Anyway, even disregarding this last observation, the mean uplift rate of $0.59 \mathrm{~mm} / \mathrm{yr}$ is similar to that calculated by Cucci and Cinti (1998) and slightly lower than that observed by Bordoni and Valensise (1998) and Lambeck et al. (2004). Samples S3 to S5 are located in the Stombi area, some kilometers off the main archeological area (fig. 6); S6, which is placed in the same locality, is the only other sample that displays positive signal $(0.33 \mathrm{~mm} / \mathrm{yr}$, table I). Therefore, the evidence is that in the Stombi area the Holocene rates of uplift are of the same order of magnitude as those calculated or suggested by several authors in the adjacent areas as a regional process. The second piece of evidence is that regional uplift is the only signal recorded between $\sim 11 \mathrm{ka}$ and $\sim 5 \mathrm{ka}$ (S3-S4-S5); it is still recorded far from the archeological area at $2.6 \mathrm{ka}$ (S6), a strong suggestion for uplift being an ongoing process.

The last observation concerns sample S9, which provides an uplift rate $(4.67 \mathrm{~mm} / \mathrm{yr}$, table I) that is apparently nonconforming with the other signals. The level that hosted the peat sample rests upon backshore sands and is covered by seaward dipping sands originated by storm waves (Cotecchia et al., 1969); these observations, along with the uncertainties on the origin of the peat level (see Section 6.2), allow us to hypothesize that the sample was deposited at some altitude above the ancient sea level so that the uplift rate calculated over such a young sample is clearly misleading.

\subsection{Subsidence}

S1-2 and S7-8 come from the Parco del Cavallo and Casa Bianca main archeological area (fig. 6) and all show negative tectonic motion. In particular, S1 and S2 are very close in age and display rates of subsidence of -1.13 and $-0.73 \mathrm{~mm} / \mathrm{yr}$, respectively (table I). Sample S7 corrected for its paleoecological minimum elevation provides a minimum subsidence rate of $-0.49 \mathrm{~mm} / \mathrm{yr}$, while the highest value of subsidence rate is achieved by S8 with -1.97 $\mathrm{mm} / \mathrm{yr}$. The evidence in this case is that the sub- sidence process is rather limited in space to the main archeological area and to the vicinity of the Crati River, while it is probably limited also in time because the oldest subsiding sample dates back to less than 4000 years BP. Nonetheless, the values of the subsidence rates in the Parco del Cavallo and Casa Bianca sites are remarkable.

A series of concurring geological causes likely originated such dramatic phenomenon of subsidence. The stratigraphies of the boreholes in the area (fig. 7) along with the evidence of sustained coastal progradation probably active since Mid-Holocene testify a rapidly evolving environment of deposition, that in the relatively short period of time of a few millennia changed from marine to continental. Therefore, we can observe in fig. 7 that the oldest archeological level found in $\mathrm{BH} 4$ and $\mathrm{BH} 5$ (Archaic Sybaris) and in BH6 (Hellenistic Thurii) always rests upon sandy deposits of dune origin that represent a quite stable horizon for human settlement. However, the archeological levels are overlain by sandy silts and silty clays of lacustrine and lagoonal origin, progressively silted up and sealed by fluvial floodings. This situation is clearly shown both in BH5, with palustrine deposits intervening between the Sybaris and Thurii levels, and alluvials covering the Hellenistic town, and in BH6, where S8 indicates a marshy environment with deposition of very fine, highly compressible sediments (fig. 7). Not far from these boreholes, S1 and S2 suggest that the subsidence process was locally already active some centuries prior to the human settlements, probably because of irregularities in the topography, with local lowlands and small paleovalleys filled by a thicker sequence of fine deposits.

$\mathrm{BH} 3$ and $\mathrm{BH} 4$ are located west of the main archeological area and farther from the Crati River. The four samples from these boreholes do not show negative tectonic motion; this fact indicates that subsidence in the area is a process of limited extent, originated by fine compressible sediments deposited either in palustrine environments or by fluvial inundations. The $\sim 2 \mathrm{~km}$ longitudinal distance of $\mathrm{BH} 3$ from the Parco del Cavallo and Casa Bianca sites suggests that, with $\sim 1 \mathrm{~m} / \mathrm{yr}$ rate of coastal progradation, this 
location likely underwent the same geological events a couple of millennia before the main archeological area. Then, if any subsidence locally took place also at the Stombi site, it did not occur before the deposition of sample S3.

The evidence that subsidence is associated with some lithological characteristics of the Holocene deposits and that it is restricted to limited sectors definitively excludes its tectonic origin. Although regional seismogenic faults have been described along the southern slope of the Pollino Chain (Vittori et al., 1995; Ferreli et al., 1996; Cinti et al., 1997, 2002), in no case does the predicted deformation field induced by those faults affect the study area (Cucci and Cinti, 1998). In addition, Cucci (2004) found no evidence for Holocene activity along two other structures located closer to the Sybaris area and precedently quoted as active (Galadini et al., 2000; Michetti et al., 2000). It is worth mentioning that besides this «lithological» subsidence another type of subsidence has been growing in recent times that is «man-induced», as it is originated by haphazard pumping from ground water. As a consequence of this, the IGM geodetic station located $2 \mathrm{~km} \mathrm{SE}$ of the Sybaris area recorded $\sim 20 \mathrm{~cm}$ lowering since 1950 (Cotecchia, 1993), with a subsidence rate several times larger than the long-term one.

\subsection{Overflooding}

The present elevation of the ground level at the archeological sites ranges between 2.5 and $5.0 \mathrm{~m}$ a.s.l.; this surface pattern must not have been very different during the time of the Magna Græcia colonies (Paladino and Troiano 1989), as $\sim 2 \mathrm{~m}$ is believed to be the minimum height for settlements safe from periodic flooding in a coastal town (Guerricchio and Melidoro, 1975; Antonioli and Leoni, 1998; Antonioli et al., 2004). Therefore it is reasonable that in the archeological area the velocity of deposition since Greek times is comparable to the rate of subsidence, so as to compensate the local negative motion of the ground. The calculated velocities of deposition shown in table II turned out to be variable at the different locales and not uniform in time. The main archeological sites show deposition rates in the range $2.6 \div 3.6 \mathrm{~mm} / \mathrm{yr}$, estimated by age and depth from the ground level of each sample. Comparable values (1.9-2.8 $\mathrm{mm} / \mathrm{yr}$ ) are obtained when the rates are calculated using the depth and the assumed age of the three archeological levels in BH5-BH6. On the contrary, S8 at Casa Bianca next to the Crati outfall (fig. 6) displays the highest rate of $5.8 \mathrm{~mm} / \mathrm{yr}$, that testifies of an increase in the flooding events during the last

Table II. Mean velocities of deposition in the Sybaris area. Location: PC - Parco del Cavallo; CB - Casa Bianca; ST - Stombi. The age of the reference level is rounded to the nearest decade.

\begin{tabular}{cccccc}
\hline \hline Location & Borehole & Reference level & $\begin{array}{c}\text { Age of reference } \\
\text { level (years BP) }\end{array}$ & $\begin{array}{c}\text { Thickness } \\
\text { of deposition (m) }\end{array}$ & $\begin{array}{c}\text { Mean deposition } \\
\text { rate (mm/yr) }\end{array}$ \\
\hline PC & BH1 & S1 & 3360 & 12.10 & 3.60 \\
PC & BH5 & S7 & 1470 & 4.10 & 2.79 \\
PC & BH5 & Sybaris & $\sim 2670$ & 7.60 & 2.85 \\
PC & BH5 & Thurii & $\sim 2400$ & 4.50 & 1.87 \\
CB & BH2 & S2 & 3530 & 9.30 & 2.63 \\
CB & BH6 & S8 & 800 & 4.65 & 5.81 \\
CB & BH6 & Thurii & $\sim 2400$ & 4.80 & 2.00 \\
ST & BH3 & S3 & 5440 & 8.75 & 1.61 \\
ST & BH3 & S5-S3 & 5780 & 52.15 & 9.02 \\
ST & BH4 & S6 & 2640 & 3.70 & 1.40 \\
\hline
\end{tabular}


eight centuries in the easternmost, recently emerged site. $\mathrm{BH} 3$ and $\mathrm{BH} 4$ in the Stombi area exhibit a quite constant mean deposition rate of $1.5 \mathrm{~mm} / \mathrm{yr}$ over the past $5.4 \mathrm{ka}$; in addition, $\mathrm{BH} 3$ also provides a striking $9.0 \mathrm{~mm} / \mathrm{yr}$ rate between 5.4 and $11.2 \mathrm{ka}$, the latter date being close to the transition (11.5-11.6 kyr BP, Alley et al., 1993; Gulliksen et al., 1998) between the cold and dry Younger Dryas and the stable, warm, high sedimentation speed Holocene.

Despite the exceptional solid load transported by the Crati and Coscile, both these rivers are not suspended above the surrounding plain; a possible explanation of such behaviour is provided by the contrast that local subsidence exerts on alluviation.

\section{Conclusions}

From the data above described, it appears that the Holocene evolution of the Sybaris Plain is the result of uplift, subsidence and overflooding, each acting with different timing and scale.

Uplift is confirmed to be the most important source of tectonic deformation at the regional scale, also during the last 10000 years. A mean $\sim 0.6 \mathrm{~mm} / \mathrm{yr}$ uplift rate was calculated over the past $11.2 \mathrm{kyr}$ at the Stombi archeological site. Therefore, Holocene rates of uplift in the Sybaris area are comparable to Late Pleistocene ones, despite the fact that they are affected by local disturbances and are averaged over a shorter time extent. At the smaller scale the regional uplift can be considered a uniform steady lift on which local signals originated by subsidence, deposition, etc. are superposed.

Active subsidence originated by deposition of very fine, highly compressible sediments at the transition between marine and continental environment is superimposed and locally outpaces regional uplift at the Parco del Cavallo and Casa Bianca sites. The rates of subsidence in the main archeological area range between $\sim 0.5 \mathrm{~mm} / \mathrm{yr}$ and $\sim 2.0 \mathrm{~mm} / \mathrm{yr}$ and are calculated over a period of $0.8 \div 3.5 \mathrm{ka}$. The absolute value of subsidence is even higher than the observed one if it is considered that the subsidence is superimposed on widespread rising originated by regional uplift. Subsidence is a relatively recent feature as it is observed only in the upper part of the stratigraphic sequence and is not recorded before 4000 years BP. The limited extent of subsidence and the short time elapsed since its inception confirm the lithological origin of the process, that in the last century was possibly overtaken by man-induced subsidence originated by irrational ground water pumping. On the contrary, there is no evidence of a fault-induced contribution to the subsidence.

Although negative net tectonic motion locally affects the archeological area, the surface morphology of this section of the plain has remained almost unchanged, as active alluvial deposition from the Crati and Coscile rivers kept pace with subsidence. Local rates of deposition are relatively lower $(1.5 \mathrm{~mm} / \mathrm{yr})$ at the Stombi site where subsidence is not observed, and range between $2.5 \mathrm{~mm} / \mathrm{yr}$ and $3.5 \mathrm{~mm} / \mathrm{yr}$ in the main archeological area. An increase in flooding events during the last eight centuries is suggested by twofold deposition rates at the Crati outfall closer to the sea. Finally, there is evidence of a general slowdown of the sedimentation following the Mid-Holocene flex of the fast trend of sea level rise.

Therefore, the Holocene history of the Sybaris Plain can be envisioned as the result of the progressive eastward migration of the land-sea boundary. Such coastal progradation, mostly originated by active alluvial deposition, has been working in the area at a mean rate of $\sim 1$ $\mathrm{m} / \mathrm{yr}$ since $\sim 7 \mathrm{ka}$, i.e. when the solid load deposited at the mouth of the main rivers of the Plain (the Crati, Coscile and Raganello rivers) started prevailing on the recovery of the MidHolocene sea. This process is confirmed by evidence of striking changes in the surface hydrography originated by the Crati and Coscile rivers, that in the past $2.5 \mathrm{kyr}$ gave place to periodic floodings and cyclic fluvial captures. In addition to sedimentation, it is suggested that regional uplift also provides a minor contribution $(\leq 0.05 \mathrm{~m} / \mathrm{yr})$ to coastal progradation.

Because of the migration of the land-sea boundary, sites that were previously submerged quickly became attractive for human settlement (stable locations, close to the coast and next to the navigable mouth of a river) about 3000 years ago. But only a few centuries afterwards 
and because of the same process those same sites were isolated, located inland from the coast and buried several meters beneath the ground. The ancient, wealthy Sybaris was one of these sites.

\section{Acknowledgements}

Thanks to the Associate Editor of the Journal, Dr. G. Scalera. Thanks also to F.R. Cinti, U. Fracassi and A. Tertulliani for having read and corrected a first draft of the manuscript. I am grateful to Dr. P. Montone and to an anonymous reviewer for constructive criticism and comments on the paper.

\section{REFERENCES}

Adamesteano, D. (1974): La Basilicata Antica, (Di Mauro, Cava dei Tirreni), pp. 241.

Alley, R.B., D.A. Meese, C.A. Shuman, A.J. Gow, K.C. TAYlor, P.M. Grootes, J.W.C. White, M. Ram, E.D. WAdDington, P.A. MAYEWSKi and G.A. Zielinski (1993): Abrupt increase in Greenland snow accumulation at the end of the Younger Dryas event, Nature, 362, 527-529.

Amato, A., B. Alessandrini, G.B. Cimini and G. Selvaggi (1993): Active and remnant subducted slabs beneath Italy: evidence from seismic tomography and seismicity, Ann. Geofis., XXXVI (2), 201-214.

Ambrosetti, P., C. Bosi, F. Carraro, N. Ciaranfi, M. PanizZA, G. PAPANI, L. VeZzANi and A. ZANFERRARI (1987): Neotectonic map of Italy, Quad. Ric. Sci., 114 (4).

ANDERSON, H. and J. JACKSON (1987): The deep seismicity of the Tyrrhenian Sea, Geophys. J. R. Astron. Soc., 91, 613-637.

Antonioli, F. and G. LEONI (1998): Siti archeologici sommersi e loro utilizzazione quali indicatori per lo studio delle variazioni recenti del livello del mare, Il Quaternario, 11 (1), 53-66.

Antonioli, F., G. Dai Pra, A.G. Segre and S. Sylos LabiNI (2004): New data on Late Holocene uplift rates in the Messina Strait area, Italy, Quaternaria Nova, VIII, 45-67.

APAT (AgENZIA PER LA PRoteZIONE DELl'AMBIENTE E PER I Servizi TeCNICI) (2004): Geological Map of Italy, edited by B. Compagnoni and F. Galluzzo (SELCA, Florence).

Argnani, A. (2000): The Southern Tyrrhenian subduction system: recent evolution and neotectonic implication, Ann. Geofis., 43 (3), 585-607.

BARberi, F., P. Gasparini, F. InNOCEnTI and L. Villari (1973): Volcanism of the Southern Tyrrhenian Sea and its geodynamical implications, J. Geophys. Res., 78, 5221-5232.
Barberi, G., M.T. Cosentino, A. Gervasi, I. Guerra, G NERI and B. ORECCHIO (2004): Crustal seismic tomography in the Calabrian Arc region, South Italy, Phys. Earth Planet. In., 147, 297-314.

Bassinot, F.C., L.D. Labeyrie, E. Vincent, X. QuiDELLEUR, N.J. SHACKLETON and Y. LANCELOT (1994): The astronomical theory of climate and the age of the Brunhes-Matuyama magnetic reversal, Earth Planet. Sci. Lett., 126, 91-108.

Bigi, G., D. Cosentino, M. Parotto, R. Sartori and P. SCANDONE (1983): Structural model of Italy, Quad. Ric. Sci., 114 (3).

Bleau, J. (1663): Le Grand Atlas, Italie, qui est le XVI Livre de l'Europe, vol. IX (Amsterdam).

Bordoni, P. and G. VAlensise (1998): Deformation of the 125 ka marine terrace in Italy: tectonic implications, in Coastal Tectonics, edited by I.S. STEWART and C. VITAFInZI, Geol. Soc. London Spec. Publ., 146, 71-110.

Cherubini, C., V. Cotecchia and R. Pagliarulo (2000): Subsidence in the Sybaris Plain (Italy), in Land Subsidence. Proceedings of the Sixth International Symposium on Land Subsidence (Ravenna, Italy), vol. I, 3-15.

Cimini, G.B. (1999): $P$-wave deep velocity structure of the Southern Tyrrhenian subduction zone from nonlinear traveltime tomography, Geophys. Res. Lett., 26, 3709. 3712.

Cinti, F.R., L. Cucci, D. Pantosti, G. D’Addezio and M. MeghraOu (1997): A major seismogenic fault in a 'silent area': the Castrovillari Fault (Southern Apennines, Italy), Geophys. J. Int., 130, 322-332.

Cinti, F.R., M. Moro, D. PAntosti, L. Cucci and G. D'ADDEZIO (2002): New constraints on the seismic history of the Castrovillari Fault in the Pollino gap (Calabria, Southern Italy), J. Seismol., 6, 199-217.

Colella, A. (1988): Fault-controlled marine Gilbert-type fan deltas, Geology, 16, 1031-1034.

Colella, A. and W.R. Normark (1984): High-resolution side-scanning sonar survey of delta slope and inner fan channels of Crati submarine fan (Ionian Sea), Mem. Soc. Geol. It., 27, 481-486.

Cotecchia, V. (1993): Incidenze geologiche e geotecniche su Sibari e la Sibaritide, in Atti del 32mo convegno di studi sulla Magna Grecia «Sibari e la Sibaritide», 7-12 Ottobre 1992, Taranto-Sibari (Istituto per la Storia e l'Archeologia della Magna Grecia, Taranto), 21-49.

Cotecchia, V., G. Dai Pra and G. Magri (1969): Oscillazioni tirreniane e oloceniche del livello del mare nel golfo di Taranto, corredate da datazioni col metodo del radiocarbonio, Geol. Appl. Idrogeol., IV, 93-138.

CucCI, L. (2004): Raised marine terraces in the Northern Calabrian Arc (Southern Italy): a 600000 years-long geological record of regional tectonic deformation, Ann. Geophysics, 47 (4), 1391-1406.

CuCCI, L. and F.R. CinTI (1998): Regional uplift and local tectonic deformation recorded by the Quaternary marine terraces on the Ionian coast of Northern Calabria (Southern Italy), Tectonophysics, 292, 67-83.

Faglia, V. (1984): Tipologia delle Torri Costiere di Avvistamento e Segnalazione in Calabria Citra e in Calabria Ultra dal XII Secolo (Istituto Italiano dei Castelli, Roma), vol. 1, 3-199.

Ferreli, L., A.M. Michetti, L. Serva, E. Vittori and E. ZAMBONELli (1996): Tettonica recente ed evidenze di 
fagliazione superficiale nella Catena del Pollino (Calabria Settentrionale), Mem. Soc. Geol. It., 51, 451-466.

Galadini, F., C. Meletti and E. Vittori (2000): Stato delle conoscenze sulle faglie attive in Italia: elementi geologici di superficie, in Le ricerche del GNDT nel campo della pericolosità sismica (1996-1999), edited by F. Galadini, C. Meletti and A. Rebez, Int. Rep. CNR-GNDT, pp. 397.

GASPARINI, P., G. IANNACCONE, P. SCANDONE and R. SCARPA (1982): Seismotectonics of the Calabrian Arc, Tectonophysics, 84, 267-286.

GIARDINI, D. and M. VELONÀ (1991): The deep seismicity of the Tyrrhenian Basin, Terra Nova, 3, 57-64.

GLiozZi, E. (1988): I terrazzi del Pleistocene superiore della penisola di Crotone (Calabria), Geol. Rom., 26, 1779.

Guerricchio, G. and G. Melidoro (1975): Ricerche di geologia applicata all'archeologia della città di Sibari sepolta, Geol. Appl. Idrogeol., 10, 107-128.

Gulliksen, S., H.H. Birks, G. Possnert and J. MANGerud (1998): A calendar age estimate of the Younger DryasHolocene boundary at Krakenes, Western Norway, Holocene, 8 (3), 249-259 .

GvirtZmanN, Z. and A. Nur (1999): Plate detachment, asthenosphere upwelling, and topography across subduction zones, Geology, 27, 563-566.

JoLIVET, L. and C. FACCENNA (2000): Mediterranean extension and the Africa-Eurasia collision, Tectonics, 19 (6), 1095-1106.

Lajoie, K.R., D.J. Ponti, C.L. Powell, S.A. Mathieson and A.M. SARNA-WoJCICKI (1991): Emergent marine strandlines and associated sediments, coastal California; a record of Quaternary sea-level fluctuations, vertical tectonic movements, climate changes, and coastal processes, in Quaternary Non-Glacial Geology: Conterminous United States, edited by R.B. MORRISON, (Geological Society of America Decade of North America Geology), vol. K-2, 190-214.

LAMBECK, K. and E. BARD (2000): Sea-level change along the French Mediterranean coast since the time of the Last Glacial Maximum, Earth Planet. Sc. Lett, 175 (34), 202-222.

LAMBECK, K. and P. Johnston (1995): Land subsidence and sea-level change: contributions from the melting of the last great ice sheets and the isostatic adjustment of the Earth, in Land Subsidence. Proceedings of the Firth International Symposium on Land Subsidence edited by F.J. BARENDS, F.J.J. BRouwer and F.H. Schroder (Balkema, Rotterdam), 3-18.

LAmbeck, K., Y. Yokoyama and T. Purcell (2002): Into and out of the Last Glacial Maximum: sea-level change during Oxygen Isotope Stages 3 and 2, Quat. Sci. Rev., 21, 343-360.

Lambeck, K., M. Anzidei, F. Antonioli, A. Benini and A. Esposito (2004): Sea level in Roman time in the Central Mediterranean and implications for recent change, Earth Planet. Sci. Lett., 224 (3-4), 563-575.

Lucente, F.P, C. ChiarabBa and G.B. Cimini (1999): Tomographic constraints on the geodynamic evolution of the Italian region, J. Geophys. Res., 104 (B9), 2030720327.

Malinverno, A. and W.B.F. RyAn (1986): Extension in the Tyrrhenian Sea and shortening in the Apennines as re- sult of arc migration driven by sinking of the litosphere, Tectonics, 5, 227-245.

Michetti, A.M., L. SERVA and E. VitTori (2000): ITHACA (Italy Hazard from Capable Faulting), a database of active capable faults of the Italian onshore territory, Database on CD-ROM, Int. Rep. of ANPA (Agenzia Nazionale Protezione Ambiente).

Morhange, C., J. Laborel and A. Hesnard (2001): Changes of relative sea level during the past 5000 years in the ancient Harbour of Marseilles, Southern France, Palaeogeogr. Palaeoclimatol. Palaeoecol., 166, 319329.

Nicolich, R., M. Laigle, A. Hirn, L. Cernobori and J. GALlARD (2000): Crustal structure of the Ionian margin of Sicily: Etna volcano in the frame of the regional evolution, Tectonophysics, 329, 121-139.

Ogniben, L., M. Parotto and A. Praturlon (1975): Structural model of Italy, Quad. Ric. Sci., 90, pp. 502.

Paladino, A. and G. Troiano (1989): Calabria Citeriore. Archeologia in provincia di Cosenza (Galasso Editore), pp. 192.

Peltier, W.R. and J.T. Andrews (1976): Glacial isostatic adjustment. The forward problem, Geophys. J. R. Astron. Soc., 46, 605-646.

Pirazzoli, P.A., G. Mastronuzzi, J.F. SAliège and P. SANsò (1997): Late Holocene emergence in Calabria, Italy, Mar. Geol., 141, 61-70.

ScAndONE, P. (1979): Origin of the Tyrrhenian Sea and Calabrian Arc, Boll. Soc. Geol. It., 98, 27-34.

Selvaggi, G. and C. ChiarabBa (1995): Seismicity and Pwave velocity image of the Southern Tyrrhenian subduction zone, Geophys. J. Int., 121, 818-826.

Siddall, M., E.J. Rohling, A. Almogi-Labin, C. HemLeben, D. Meischner, I. SCHMElzer and D.A. SMEed (2003): Sea-level fluctuations during the last glacial cycle, Nature, 423, 853-858.

Strabo, Geography, The Perseus Digital Library, Tufts University (on line: http://www.perseus.tufts.edu).

Stuiver, M., P.J. Reimer, E. BARd, J.W. Beck, G.S. Burr, K.A. Hughen, B. Kromer, F.G. McCormac, J. Van DER PLICHT and M. SPURK (1998): INTCAL98 radiocarbon age calibration, 24000-0 cal BP, Radiocarbon, 40 (3), 1041-1083.

Tiné, V. and A. Traverso (1993): Il villaggio di Favella della Corte e la neolitizzazione della Sibaritide, in Atti del 32 mo convegno di studi sulla Magna Grecia «Sibari e la Sibaritide», 7-12 ottobre 1992, Taranto-Sibari (Istituto per la storia e l'archeologia della Magna Grecia, Taranto), 85-94.

ThuCYDIDEs, The Peloponnesian War, The Perseus Digital Library, Tufts University (on line: http://www.perseus.tufts.edu)

Vittori, E., L. Ferreli, A.M. Michetti and L. Serva (1995): Holocene paleo-earthquakes along the Pollino fault zone (Northern Calabria-Italy): implications for seismic hazard assessment, in Proceedings of the Fifth International Conference on Seismic Zonation (EETI, AFPS), Nice, 1400-1407.

Waelbroeck, C., L. Labeyrie, E. Michel, J.C. Duplessy, J.F. McManus, K. LAmbeCK, E. Balbon and M. LABRACHERIE (2002): Sea-level and deep water temperature changes derived from benthic foraminifera isotopic records, Quat. Sci. Rev., 21, 295-305. 
WESTAWAY, R. (1993): Quaternary uplift of Southern Italy, J. Geophys. Res., 98, 21741-21772.

Zecchi, R., G. Giorgi, F. Francavilla and A. Ronchi (2003): Tendenze evolutive recenti del delta del fiume Crati (Calabria-Italy) sulla base della cartografia storica e delle immagini telerilevate, in Atti $7^{\circ}$ Confe- renza Nazionale ASITA, Verona 2003 (on line: http://www.asita.it/7/atti7.html).

(received June 24, 2005;

accepted October 27, 2005) 